\title{
Parathyroid hormone levels after parathyroidectomy for secondary hyperparathyroidism
}

\author{
Climério Pereira Nascimento Junior ${ }^{1 *}$ (1), Sergio Samir Arap ${ }^{1}$ (), Melani Ribeiro Custodio ${ }^{2}$ (b), \\ Ledo Mazzei Massoni Neto' (1D, Marília D`Elboux Guimarães Brescia' (1), \\ Rosa Maria Affonso Moyses² (1), Vanda Jorgetti² (1), Fabio Luiz de Menezes Montenegro ${ }^{1}$
}

\begin{abstract}
SUMMARY
OBJECTIVE: The parathormone level after parathyroidectomy in dialysis patients are of interest. Low levels may require cryopreserved tissue implantation; however, the resection is necessary in case of recurrence. We analyzed post parathyroidectomy parathormone levels in renal hyperparathyroidism.

METHODS: Prospective observation of postoperative parathormone levels over defined periods in a cohort of dialysis patients that underwent total parathyroidectomy and immediate forearm autograft from 2008 to 2010, at a single tertiary care hospital.

RESULTS: Of 33 patients, parathormone levels until 36 months could be divided into four patterns. Patients with stable function (Pattern 1) show relatively constant levels after two months (67\% of the cases). Early function and later failure (Pattern 2) were an initial function with marked parathormone reduction before one year (18\%). Graft recurrence (Pattern 3) showed a progressive increase of parathormone in four cases (12\%). Complete graft failure (Pattern 4) was a nonfunctioning implant at any period, which was observed in one patient (3\%). Parathormone levels of Pattern 3 became statistically different of Pattern 1 at 36 months.

CONCLUSIONS: Patients that underwent the total parathyroidectomy and autograft present four different graft function patterns with a possible varied therapeutic management.

KEYWORDS: Parathyroid glands. Hyperparathyroidism. Hyperparathyroidism, secondary. Parathyroidectomy. Parathyroid hormone.
\end{abstract}

\section{INTRODUCTION}

Secondary hyperparathyroidism in dialysis patients (2HPT) may require parathyroidectomy, especially in developing countries, where $10.7 \%$ of patients under dialysis have parathyroid hormone (PTH) levels greater than $1,000 \mathrm{pg} / \mathrm{mL}^{1}$. Parathyroidectomy is effective, and its costs are lower than the use of cinacalcet in the long-term ${ }^{2}$. Surgical treatment may improve the long-term survival in dialysis patients with advanced $2 \mathrm{HPT}^{3}$.

In general, these patients are seen by nephrologists after surgery with great relief of bone pain and other symptoms $s^{4}$.
Recently, the Kidney Disease: Improving Global Outcome (KDIGO) guidelines suggested that PTH should be maintained between two and nine times the upper limit of the $\operatorname{method}^{5}$. The best postoperative PTH levels have not been defined yet ${ }^{6,7}$.

We performed a prospective observational study of a cohort of patients with severe 2HPT to observe the PTH levels after parathyroidectomy. A classification of patients in four different patterns could be suggested, with possible helpful clinical implications.

\footnotetext{
'Universidade de São Paulo, Serviço de Cirurgia de Cabeça e Pescoço - São Paulo (SP), Brasil.

¿Universidade de São Paulo, Departamento de Clínica Médica, Serviço de Nefrologia - São Paulo (SP), Brasil.

*Corresponding author: climeriojr@yahoo.com.br

Conflicts of interest: the authors declare there is no conflicts of interest. Funding: none.

Received on July 22, 2020. Accepted on July 26, 2020.
} 


\section{METHODS}

We included dialysis patients operated for 2HPT from January 2008 to February 2010 and followed up for 36 months in a single tertiary university institution. The Institutional Review Board approved the study. All participants provided their informed consent.

Intended total parathyroidectomies and immediate heterotopic forearm parathyroid autografts were performed. Pieces of the less diseased parathyroid were selected macroscopically and autografted in the forearm, with multiple or single pockets, as described in previous papers ${ }^{8}$.

The analysis included the age at parathyroidectomy, gender, parathyroid graft non-function, graft recurrence (defined here as graft-dependent non-suppressible elevated levels of PTH six months after the parathyroidectomy), and implantation of cryopreserved tissue. We studied the following biochemical parameters before and after the operation: total calcium $(\mathrm{tCa}$, reference range $8.6-10.2 \mathrm{mg} / \mathrm{dL}$ ), ionized calcium (iCa, $4.6-5.3 \mathrm{mg} / \mathrm{dL}$ ), phosphorus (P, $2.7-4.5 \mathrm{mg} / \mathrm{dL}$ ), and PTH (16-87 pg/mL). Preoperative alkaline phosphatase (AP, 35-104 U/L, for women and 40-129 U/L for men) and 25-hydroxy-vitamin D3 (Vitamin $\mathrm{D}, 30-100 \mathrm{ng} / \mathrm{mL}$ ) were also included, when available.

Individual systemic levels of PTH (sPTH) were considered before the operation, until the first 15 days and, 1, 2, 3, 4, 6, $9,12,18,24$ and 36 months after the operation. We initially searched for possible different patterns of autograft profile for graft non-function or hypofunction (low or undetectable PTH), adequate function (PTH in normal or target levels, with long-standing stability), and graft recurrence (high non-suppressible sPTH)

\section{RESULTS}

There were 33 patients (19 males and 14 females) who were followed-up properly during the study period. Their ages ranged from 24 to 62 years (mean=45.2, SD=10.1). Preoperative laboratory results are presented in Table 1 .

Some different patterns of sPTH levels attributable to implant secretion were observed until 36 months of follow up (Table 2).

In 22 cases (67\%), there was a relatively stability in systemic PTH (Pattern 1). Interestingly, two cases had a significant decrease of sPTH when iatrogenic hypercalcemia ensued (values of 0 and $3 \mathrm{pg} / \mathrm{mL}$ ). After normalization of calcium, PTH levels were 98 and $104 \mathrm{pg} / \mathrm{mL}$. These two events occurred more than 12 months postoperatively. Conversely, in 15 cases, isolated or repetitive episodes of hypocalcemia did not increase $\mathrm{sPTH}$ (median values at $6,12,24$ and 36 months were, respectively, $42,40.5,30,30)$. In two cases, the attempt to improve PTH levels with cryopreserved parathyroid tissue had no impact in the PTH levels in one of them (21 months of storage) and a possible function in the other one (23 months of storage).
Six patients (18\%) presented initial good implant function. However, very low or undetected levels of systemic PTH ensued after 12 months, despite significant hypocalcemic stimulus (Pattern 2). Of these, two had cryopreserved parathyroid autografting at nine and 23 months postoperatively. Only the latter implant showed evidence of good function. After repeated undetectable $\mathrm{sPTH}$, there was detectable graft and $\mathrm{sPTH}$ six months after transplantation: 1672 and $17 \mathrm{pg} / \mathrm{mL}$, respectively. There was a sustained systemic level at least after 16 months of the implant. This patient had a biopsy of the failed graft during cryopreserved transplantation. There was interstitial fibrosis.

There was a progressive elevation of sPTH levels in four cases (Pattern 3). In two of these patients, PTH levels were still acceptable according to KDIGO recommendations (248 and $185 \mathrm{pg} / \mathrm{mL}$ ), and they were under observation before a possible graft excision. In one patient, high PTH was considered clinically significant because of sustained hypercalcemia and this graft was eventually excised at the $38^{\text {th }}$ month after surgery, when PTH was $471 \mathrm{pg} / \mathrm{mL}$ and tCa was $10.7 \mathrm{mg} / \mathrm{dL}$. The last case is still under investigation: despite sPTH level as high as $1,006 \mathrm{pg} / \mathrm{mL}$ (simultaneous graft value of 2,063 $\mathrm{pg} / \mathrm{mL}$ ), marked and sustained hypocalcemia $(\mathrm{tCa}=7.8 \mathrm{mg} /$ $\mathrm{dL}$ and $\mathrm{iCa}=3.84 \mathrm{mg} / \mathrm{dL}$ ) is still present. Bone biopsy of this patient at the $33^{\text {rd }}$ month was compatible with osteoporosis and mixed bone disease.

In only one patient, all postoperative $\mathrm{PTH}$ values were zero, even after cryopreserved tissue grafting at the $18^{\text {th }}$ month (Pattern 4). This patient had a preoperative PTH of $1,507 \mathrm{pg} / \mathrm{mL}$.

Patients with progressive increase of PTH levels (tendency to recurrence) had a non-significant higher level of PTH when compared to stable patients until 24 months, except at the $18^{\text {th }}$ month ( $\mathrm{p}=0.04$, Mann-Whitney's test). Figure 1 shows that at the $36^{\text {th }}$ month, the difference became clearly significant $(\mathrm{p}=0.003$, Mann-Whitney's test).

The highest ratios between PTH measured in the autograft arm and sPTH at 6, 12, 24 and 36 months were 146, 74, 89, and 74. In Pattern 3, the highest ratios were 15, 3, 6, and 2, respectively. In Pattern 1, the respective ratios were 146, 74, 89, and 74. In Pattern 2, ratios were 109, 12, 16, and 73.

Altogether, seven patients underwent renal transplantation after the parathyroidectomy $(21.2 \%)$. The mean time from the parathyroid operation to kidney transplantation was 20 months ( $\mathrm{SD}=8.3$; 95\%CI 12.3-27.7). One male patient lost the kidney graft a few days after receiving it, and he restarted dialysis (he is in Pattern 1 group). All the others are doing well. Of these successful cases, five were in Pattern 1 and one in Pattern 4. The exclusion of these cases from the analysis did not affect the results of previous comparisons of Patterns 1, 2, and 3. 


\section{DISCUSSION}

In the present study, we showed that autograft parathyroid tissue in $2 \mathrm{HPT}$ has a stable tendency in most patients, at least until 36 months after the operation. This tissue seems to be sensitive to calcium, with marked decrease in PTH secretion during periods of unintentional iatrogenic hypercalcemia. Even though uremic milieu is considered a constant stimulation to parathyroid hyperplasia, these implants are only capable of secreting a maximum quantity of PTH. One possible explanation for these observations is that the implanted tissue is still not autonomous and its response is physiological, as noted in other studies ${ }^{9}$. In these cases, the upper limit of secretion is most likely determined by the autografted tissue mass. Interestingly, this tissue seems to be rather "resistant" to continuous stimulation of uremia. Consequently, letting patients hypocalcemic will not elevate the PTH significantly. In that case, the only possibility to elevate sPTH to target levels of KDIGO would be cryopreserved tissue grafting. A cryopreserved tissue may present function even after long periods of storage in some patients ${ }^{10}$. Possibly, a long delay from harvesting until cryopreservation processing affected that result ${ }^{11}$.

Uremic stimulation is commonly considered to lead to a progressive increase in the PTH levels over time, although it occurs in few cases, only $12 \%$ in our series. This observation requires caution when considering total parathyroidectomy without immediate autograft in all patients under dialysis ${ }^{12}$. Low levels of PTH may have deleterious effects ${ }^{13}$.

Another fact described herein and in previous papers suggest that despite good initial function, late failure is possible ${ }^{14}$.
The frequency of this problem seems to be clinically relevant, affecting almost one in five patients. The cause is unclear, but progressive fibrosis encircling the graft may be questioned. It seems wise to keep cryopreserved parathyroid tissue for periods not lower than one year ${ }^{15}$.

Some patients presented a considerably higher rate of PTH secretion by the graft, which is not affected by unintentional iatrogenic hypercalcemia, during the early periods of parathyroidectomy (data not shown). In these cases, there may be a significant number of autonomous cells in the autografted tissue, as demonstrated by others ${ }^{9}$. In some cases, $\mathrm{sPTH}$ shows a progressive increase earlier, but the recurrence may not be clear until long-term follow-up. The PTH should be measured at least once a year to identify the recurrence before any symptom or consequence occurs.

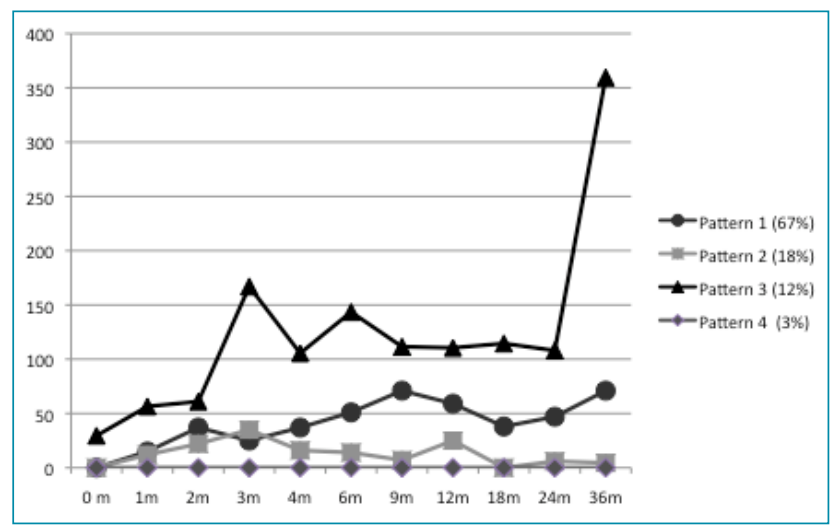

Figure 1. Patterns of implant function after the parathyroidectomy. Each point represents the median value at different periods.

Table 1. Preoperative biochemical parameters of patients undergoing parathyroidectomy.

\begin{tabular}{l|c|c|c|c|c|c|c} 
& $\mathrm{tCa}(\mathrm{mg} / \mathrm{dL})$ & $\mathrm{iCa}(\mathrm{mg} / \mathrm{dL})$ & $\mathrm{P}(\mathrm{mg} / \mathrm{dL})$ & $\mathrm{PTH}(\mathrm{pg} / \mathrm{mL})$ & $\begin{array}{c}\mathrm{tCa} X \mathrm{P} \\
\left(\mathrm{mg}^{2} / \mathrm{dL}^{2}\right)\end{array}$ & $\mathrm{AP}(\mathrm{U} / \mathrm{L})$ & Vit D (ng/mL) \\
\hline minimum & 7.6 & 4.1 & 2.0 & 788 & 20.4 & 66 & 7.8 \\
\hline maximum & 12.4 & 5.7 & 9.4 & 5439 & 102.5 & 1694 & 50.1 \\
\hline mean (SD) & $10.0(0.9)$ & $5.1(0.4)$ & $5.8(1.6)$ & $\begin{array}{c}2036^{*} \\
(1528-3056)\end{array}$ & $58.8(18.6)$ & $\begin{array}{c}432^{*} \\
(221-636.5)\end{array}$ & $24.7(11.4)$ \\
\hline
\end{tabular}

*Median and interquartile range for non-parametric distributions by Kolmogorov-Smirnov Test. tCa: total calcium; iCa: ionized calcium; P: phosphorus; PTH: parathyroid hormone; tCa X P: calcium-phosphorus product; AP: alkaline phosphatase; Vit D: vitamin D.

Table 2. Median PTH values and interquartile range $(\mathrm{pg} / \mathrm{mL})$ before and after the parathyroidectomy. Time in months after the operation $(\mathrm{m})$.

\begin{tabular}{l|c|c|c|c|c|c|c|c} 
& Preoperative & $0 \mathrm{~m}$ & $1 \mathrm{~m}$ & $2 \mathrm{~m}$ & $6 \mathrm{~m}$ & $12 \mathrm{~m}$ & $24 \mathrm{~m}$ & $36 \mathrm{~m}$ \\
\hline Pattern 1 & 2026 & 0 & 15 & 37 & 51 & 59 & 47 & 71 \\
$\mathrm{n}=22$ & $1458-4098$ & $0-40.8$ & $0-39.5$ & $10-85$ & $25.5-89.2$ & $28.5-94$ & $23.5-113.5$ & $30-100$ \\
\hline Pattern 2 & 2138 & 0 & 19 & 26 & 28.5 & 21 & 3 & 4.5 \\
$\mathrm{n}=6$ & $2003-2421$ & $0-14.2$ & $4.5-311.8$ & $13.5-107.3$ & $9.5-94.8$ & $8.2-59$ & $0.0-15.8$ & $0.8-10.5$ \\
\hline Pattern 3 & 2075 & 29.50 & 56.5 & 61 & 143 & 110.5 & 108 & 359.5 \\
$\mathrm{n}=4$ & $1092-2492$ & $0-166.3$ & $7.5-123.5$ & $47.25-277.3$ & $2.75-297.8$ & $58.75-646.8$ & $53.75-772.8$ & $200.8-872.3$ \\
\hline
\end{tabular}


Another useful piece of information is that PTH levels in graft arm vary widely during the follow-up. The specific site of puncture or different time of day may drastically affect the results. The simultaneous determination of the PTH levels in each forearm seems to be the most reliable method to obtain direct and useful evidence of graft function to predict recurrence ${ }^{16,17}$. Based on our present experience, graft arm PTH only indicates some graft function as the possible source of sPTH. Any decisions regarding autograft excision should be based only on repeated sPTH levels with or without suppression of graft arm secretion ${ }^{18}$.

Despite rare, total failure of the graft is a significant problem, as absence of PTH is associated with adynamic bone disease ${ }^{19}$. The cause is still unclear. In a previous study of parathyroid ultrastructure before cryopreservation, tissue showed signs of irreversible cellular damage right after harvesting in one of 11 cases $(9 \%)^{11}$. In some cases, the surgical approach may trigger irreversible cell damage.

It is hard to explain why a patient with very high levels of PTH (close to $1,000 \mathrm{pg} / \mathrm{mL}$ ) presents hypocalcemia more than two years after parathyroidectomy. At this time, hungry bone is not expected. Perhaps, a large amount of 7-84 PTH fragments is present in this patient. These fragments are not able to improve calcemia or even may induce the patient's hypocalcemia ${ }^{20}$. The study of different circulating forms of PTH in similar cases may give interesting clues to parathyroid cell and PTH function.

In a prospective study, graft-dependent recurrence was $2.85 \%$. If we consider that only one case had graft excision up to the conclusion of this paper, we have a similar rate (3\%). Interestingly, the same study has a graphic of PTH levels at different postoperative periods. Apparently, at 150 weeks (37 months approximately) after the operation, there were 5 out of 35 initial cases (14\%) of increasing $\mathrm{PTH}^{18}$. This seems quite comparable to our observation of $12 \%$ of Pattern C, with levels markedly different at 36 months. The true comparison is difficult as individual data are not available ${ }^{21}$.

Recurrence after parathyroid autograft in type 1 multiple endocrine neoplasia is apparently less frequent and occurs later than that observed in renal hyperparathyroidism ${ }^{22}$. This indicates that different parathyroid disease mechanisms affect graft function, and they are not comparable.

\section{CONCLUSIONS}

Patients that undergo total parathyroidectomy and autograft present four different patterns of graft function with possible different therapeutic management. Most patients evolved with stable parathyroid hormone levels.

\section{AUTHORS" CONTRIBUTION}

CPNJ: Conceptualization, Formal Analysis, Investigation, Methodology, Resources, Validation, Visualization, Writing Original Draft, Writing-Review \& Editing. SSA: Conceptualization, Formal Analysis, Investigation, Methodology, Validation, WritingReview \& Editing. MRC: Conceptualization, Formal Analysis, Investigation, Methodology, Validation, Writing - Review \& Editing. LMMN: Conceptualization, Formal Analysis, Investigation, Methodology, Validation, Writing - Review \& Editing. MDGB: Conceptualization, Formal Analysis, Investigation, Methodology, Validation, Writing-Review \& Editing. RMAM: Conceptualization, Formal Analysis, Investigation, Methodology, Validation, Writing Review \& Editing. FLMM: Conceptualization, Formal Analysis, Investigation, Methodology, Validation, Writing - Review \& Editing. VJ: Conceptualization, Formal Analysis, Investigation, Methodology, Project Administration, Supervision, Validation, Writing - Review \& Editing.

\section{REFERENCES}

1. Oliveira RB, Silva EN, Charpinel DM, Gueiros JE, Neves CL, Sampaio EA, et al. Secondary hyperparathyroidism status in Brazil: Brazilian census of parathyroidectomy. J Bras Nefrol. 2011;33(4):457-62. PMID: 22189810

2. Komaba H, Moriwaki K, Goto S, Yamada S, Taniguchi M, Kakuta T, etal. Cost-effectiveness of cinacalcet hydrochloride for hemodialysis patients with severe secondary hyperparathyroidism in Japan. Am J Kidney Dis. 2012;60(2):262-71. https://doi.org/10.1053/.ajkd.2011.12.034

3. Goldenstein PT, Elias RM, Pires de Freitas do Carmo L, Coelho FO, Magalhães LP, Antunes GL, et al. Parathyroidectomy improves survival in patients with severe hyperparathyroidism: a comparative study. PLoS One. 2013;8(8):e68870. https:// doi.org/10.1371/journal.pone.0068870
4. Alves Filho W, van der Plas WY, Brescia MDG, Nascimento Jr CP, Goldenstein PT, Massoni Neto LM, et al. Quality of life after surgery in secondary hyperparathyroidism, comparing subtotal parathyroidectomy with total parathyroidectomy with immediate parathyroid autograft: prospective randomized trial. Surgery. 2018;164(5):978-85. https://doi.org/10.1016/j. surg.2018.06.032

5. Kidney Disease: Improving Global Outcomes (KDIGO) CKD-MBD Work Group. KDIGO clinical practice guideline for the diagnosis, evaluation, prevention, and treatment of Chronic Kidney Disease-Mineral and Bone Disorder (CKDMBD). Kidney Int Suppl. 2009;(113):S1-130. https://doi. org/10.1038/ki.2009.188 
6. Montenegro FL, Brescia MD, Nascimento Júnior CP, Massoni Neto LM, Arap SS, Santos SR, et al. The deceptive concept of hypoparathyroidism and recurrence after parathyroidectomy in dialysis patients: are we offering a Procrustean bed to some patients? Rev Col Bras Cir. 2016;43(5):327-33. https://doi. org/10.1590/0100-69912016005002

7. Kakani E, Sloan D, Sawaya BP, El-Husseini A, Malluche HH, Rao M. Long-term outcomes and management considerations after parathyroidectomy in the dialysis patient. Semin Dial. 2019;32(6):541-52. https://doi.org/10.1111/sdi.12833

8. Caliseo CT, Santos SR, Nascimento Júnior CP, Arap SS, Brandão LG, Montenegro FL. Functional results of parathyroid autotransplantation in one single pocket for treatment of secondary hyperparathyroidism. Rev Col Bras Cir. 2011;38(2):85-9. https://doi.org/10.1590/s0100-69912011000200003

9. Conti-Freitas LC, Foss-Freitas MC, Lucca LJ, Costa JA, Mamede RC, Foss MC. Dynamics of parathyroid hormone secretion after total parathyroidectomy and autotransplantation. World J Surg. 2009;33(7):1403-7. https://doi.org/10.1007/s00268009-0057-8

10. Montenegro FLM, Custódio MR, Arap SS, Reis LM, Sonohara S, Castro IV, et al. Successful implant of long-term cryopreserved parathyroid glands after total parathyroidectomy. Head Neck. 2007;29(3):296-300. https://doi.org/10.1002/hed.20506

11. Barreira CE, Cernea CR, Brandão LG, Custódio MR, Caldini ET, Montenegro FLM. Effects of time on ultrastructural integrity of parathyroid tissue before cryopreservation. World J Surg. 2011;35(11):2440-4. https://doi.org/10.1007/s00268-0111261-x

12. Conzo G, Perna A, Candela G, Palazzo A, Parmeggiani D, Napolitano S, et al. Long-term outcomes following "presumed" total parathyroidectomy for secondary hyperparathyroidism of chronic kidney disease. G Chir. 2012;33(11-12):379-82. PMID: 23140920

13. Fotheringham J, Balasubramanian SP, Harrison B, Wilkie M. Post-parathyroidectomy parathyroid hormone levels: the impact on patient survival: a single-centre study in a stage 5 chronic kidney disease population. Nephron Clin Pract. 2011;119(2):c113-20. https://doi.org/10.1159/000326683

14. Mozes MF, Soper WD, Jonasson O, Lang GR. Total parathyroidectomy and autotransplantation in secondary hyperparathyroidism. Arch Surg. 1980;115(4):378-85. https:// doi.org/10.1001/archsurg.1980.01380040012002
15. Schneider R, Ramaswamy A, Slater EP, Bartsch DK, Schlosser K. Cryopreservation of parathyroid tissue after parathyroid surgery for renal hyperparathyroidism: does it really make sense? World J Surg. 2012;36(11):2598-604. https://doi. org/10.1007/s00268-012-1730-x

16. Walgenbach $S$, Hommel $G$, Junginger T. Prospective study of parathyroid graft function in patients with renal hyperparathyroidism after total parathyroidectomy and heterotopic autotransplantation by measurement of the intact parathyroid hormone concentrations in both antecubital veins. Eur J Surg. 1999;165(4):343-50. https:// doi.org/10.1080/110241599750006884

17. Arap SS, Cordeiro AC, Brandão LG, Ferraz AR, Michaluart Júnior P, Tavares MR, et al. Hiperparatireoidismo secundário: fatores prognósticos de recidiva atribuída ao implante após paratireoidectomia total e auto-implante. Rev Bras Cir Cabeça Pescoço. 2010 [cited on May 21, 2021];39(1):24-32. Available from: http://sbccp.org.br/revista-sbccp/revista-sbccp-2010/

18. Schlosser $K$, Sitter $H$, Rothmund M, Zielke A. Assessing the site of recurrence in patients with secondary hyperparathyroidism by a simplified Casanova autograftectomy test. World J Surg. 2004;28(6):583-8. https://doi.org/10.1007/s00268-004-7321-8

19. Barreto FC, Barreto DV, Moysés RM, Neves KR, Canziani ME, Draibe SA, et al. K/DOQI-recommended intact PTH levels do not prevent low-turnover bone disease in hemodialysis patients. Kidney Int. 2008;73(6):771-7. https://doi.org/10.1038/ sj.ki.5002769

20. D'Amour P. Acute and chronic regulation of circulating PTH: significance in health and in disease. Clin Biochem. 2012;45(12):964-9. https://doi.org/10.1016/j. clinbiochem.2012.04.029

21. Echenique-Elizondo $M$, Amondarain JA, Vidaur F, Olalla $C$, Aribe F, Garrido A, et al. Evaluation of parathyroid function in presternal subcutaneous grafting after total parathyroidectomy for renal hyperparathyroidism. Cir Esp. 2007;82(3):155-60. https://doi.org/10.1016/s0009-739x(07)71691-3

22. Montenegro FL, Lourenço Júnior DM, Tavares MR, Arap SS, Nascimento Júnior CP, Massoni Neto LM, et al. Total parathyroidectomy in a large cohort of cases with hyperparathyroidism associated with multiple endocrine neoplasia type 1: experience from a single academic center. Clinics (Sao Paulo). 2012;67(Suppl 1):131-9. https://doi. org/10.6061/clinics/2012(sup01)22 